\title{
Transthoracic lung ultrasound in children with signs of acute lower respiratory infection
}

\author{
Przezklatkowe badanie ultrasonograficzne płuc u dzieci z objawami ostrej infekcji \\ dolnych dróg oddechowych
}

\begin{abstract}
Pneumonia, which may be accompanied by the full spectrum of various clinical symptoms, with the most common including fever, chills, cough, chest pain, dyspnoea, tachypnoea, hypoxia, and auscultatory changes (crepitations, rales), is one of the most common lower respiratory infections. Chest radiography is a standard method used to confirm pneumonia. Transthoracic lung ultrasound has recently emerged as an alternative to radiology. The aim of this paper was to assess the utility of transthoracic lung ultrasound as an alternative to chest radiography in children with clinical manifestations of acute lower respiratory infection. A total of 63 patients aged between 1 month and 18 years, hospitalised in the Department of Paediatrics, Paediatric Nephrology and Allergology were qualified for the study. The study group included 44 children (mean age $4.3 \pm 4.4$ years), and the control group included 19 children (mean age $6.5 \pm 3.8$ years). Cough $(42 / 44,95 \%)$, dyspnoea $(31 / 44,70 \%)$, and fever $(28 / 44,64 \%)$ were the most common clinical symptoms in the study group. Auscultatory manifestations typical of pneumonia, i.e. crepitations, rales, reduced vesicular murmur, were observed in 30/44 (68\%) patients; uncertain clinical symptoms of lower respiratory infection were observed in 14/44 (32\%) patients. Lung ultrasound was performed within 48 hours of chest radiology. Both ultrasonographic and radiological lesions typical of pneumonia were found in 25/30 children presenting with clinical symptoms of pneumonia; no lesions in either of the modalities used were detected in 1/30 patients. Both ultrasonographic and radiological lesions typical of pneumonia were identified in 8/14 children with clinically uncertain pneumonia; no lesions were detected in diagnostic imaging in 1/14 children. Conclusions: Lung ultrasound is a useful tool for the assessment of lower respiratory inflammation in children. Ultrasonographic findings are comparable with those in radiology, which is considered a standard modality.
\end{abstract}

Keywords: lung ultrasound, paediatrics, pneumonia

Streszczenie Jedną z najczęstszych infekcji dolnych dróg oddechowych jest zapalenie płuc, mogące przebiegać z całym spektrum różnych objawów klinicznych, spośród których najczęstsze są: gorączka, dreszcze, kaszel, ból w klatce piersiowej, duszność, przyspieszony oddech, hipoksja oraz zmiany osłuchowe (trzeszczenia, rzężenia). Metodą referencyjną służącą do potwierdzenia zapalenia płuc jest badanie radiologiczne klatki piersiowej. Alternatywą dla badań radiologicznych stało się w ostatnich latach przezklatkowe badanie ultrasonograficzne płuc. Celem pracy była ocena przydatności przezklatkowej ultrasonografii płuc jako metody alternatywnej dla badania radiologicznego klatki piersiowej u dzieci z klinicznymi objawami ostrej infekcji dolnych dróg oddechowych. Do badania zakwalifikowano 63 pacjentów hospitalizowanych w Klinice Pediatrii Nefrologii i Alergologii Dziecięcej w wieku od 1. miesiąca do 18. roku życia. Do grupy badanej włączono 44 dzieci (średnia wieku 4,3 $\pm 4,4$ roku), grupę kontrolną stanowiło 19 dzieci (średnia wieku 6,5 $\pm 3,8$ roku). Najczęstszymi objawami klinicznymi w grupie badanej był kaszel - 42/44 (95\%), duszności - 31/44 (70\%), gorączka - 28/44 (64\%) pacjentów. U 30/44 (68\%) dzieci obecne były objawy osłuchowe typowe dla zapalenia płuc, tj. trzeszczenia, rzężenia, ściszenie szmeru pęcherzykowego; 14/44 (32\%) pacjentów miało wątpliwe klinicznie objawy infekcji dolnych dróg oddechowych. Badanie ultrasonograficzne płuc przeprowadzano w ciągu 48 godzin od wykonania badania radiologicznego klatki piersiowej. U 25/30 dzieci z klinicznymi objawami zapalenia płuc zmiany typowe dla zapalenia płuc zaobserwowano zarówno w badaniu radiologicznym, jak i w badaniu ultrasonograficznym; u 1/30 nie odnotowano zmian w żadnym z obydwu badań obrazowych. U 8/14 dzieci z wątpliwym klinicznie rozpoznaniem zapalenia płuc zmiany typowe dla zapalenia płuc zaobserwowano zarówno w badaniu radiologicznym, jak i ultrasonograficznym; u 1/14 nie odnotowano zmian w badaniach obrazowych. Wnioski: Przezklatkowe badanie ultrasonograficzne płuc jest przydatne w ocenie stanów zapalnych dolnych dróg oddechowych u dzieci, a wyniki badań ultrasonograficznych są porównywalne z przyjętym za referencyjne badaniem radiologicznym. 


\section{INTRODUCTION}

$\mathrm{P}$ neumonia, which is defined as acute infection mainly involving pulmonary alveoli and interstitial tissue, bronchioles and small bronchi, is one of the most common infections of the lower respiratory tract ${ }^{(1)}$. The most common clinical manifestations include fever, shivers, cough, dyspnoea, tachypnoea, hypoxia, and auscultatory changes (crepitations, rales) ${ }^{(1,2)}$. Chest radiography is a standard method used to confirm pneumonia ${ }^{(1,3)}$. Radiological findings are not always a condition for diagnosis in the paediatric population, which results from the lack of clear criteria, significant variability in radiographic interpretation and a tendency to limit the exposure to ionising radiation ${ }^{(2)}$.

Transthoracic lung ultrasound (TLUS) has recently emerged as an alternative to radiography, especially in children. Since lung ultrasound may be performed in virtually any setting, it is useful both in the diagnostic process and treatment monitoring. Pneumonic lesions are detectable using ultrasound if they are adjacent to the pleural line; however, studies showed that up to $98 \%$ of clinically significant lesions are located below the pleural line ${ }^{(4)}$. Normally aerated lungs are unavailable in ultrasound due to the phenomenon of acoustic impedance ${ }^{(3)}$. This changes in the case of reduced lung aeration (oedema, inflammation, atelectasis), which leads to formation of various ultrasonographic artifacts allowing for differentiation ${ }^{(3)}$.

Ultrasonographic pneumonic lesions may be classified as parenchymal, pleural and vascular ${ }^{(5,6)}$.

\section{Parenchymal criteria of pneumonia in TLUS}

Consolidations, i.e. inhomogeneous, low-echoic areas resembling an ultrasound image of the liver, are an equivalent of inflammatory pulmonary parenchymal lesions. They are usually triangular and may vary in size ${ }^{(7)}$. The presence of an air bronchogram, i.e. trapped air inside a consolidation resembling a bronchial tree, which is also seen in radiography or computed tomography (CT), is a characteristic symptom ${ }^{(5)}$. Fluid bronchogram, which is observed at an early stage of pneumonia and corresponds to airway exudates, is less commonly seen. In the case of severe inflammatory or necrotic lesions, hypoechoic or anechoic circular structures corresponding to abscesses or micro-abscesses may be seen within the consolidations ${ }^{(7)}$.

B-lines are one of the most common artifacts indicating pathology in lung ultrasonography. Vertical hyperechoic B-lines form on the pleural line, are visible along the entire length of the screen and move in accordance with pleural movements. They are believed to be generated by a small amount of liquid below the pulmonary pleura, most often in the interlobular septa ${ }^{(8,9)}$. Interstitial syndrome is defined as the presence of at least $3 \mathrm{~B}$-lines $<7 \mathrm{~mm}$ apart in one intercostal space in a single scan. B-lines $\leq 3 \mathrm{~mm}$ apart are defined as alveolar-interstitial syndrome. Artifacts are usually observed in

\section{Pleural criteria of pneumonia in TLUS}

The presence of pleural fluid is another symptom indicative of pneumonia. Pleural fluid is seen on ultrasound as a sickle-shaped anechoic space between the diaphragm and the lung, in the costodiaphragmatic recess ${ }^{(11)}$. Depending on the patient's position and the location of inflammatory lesions, the fluid may be parallel to the pleural surface or occur locally just above the focal lesion ${ }^{(12)}$. In paediatric population, the fluid is usually exudative in nature ${ }^{(1)}$; therefore, it appears hypoechoic or anechoic on ultrasound. In the case of purulent pleuritis, the fluid will be cloudy, with higher and inhomogeneous echogenicity, and it may coexist with septa in persisting inflammation ${ }^{(4)}$.

Massive exudate may cause atelectasis of the pulmonary parenchyma due to compression. The atelectasis area is usually wedge-shaped, hypoechoic with a homogeneous structure, slightly delineated from healthy parenchyma, with completely reduced or no aeration, and it moves according to the respiratory phase or cardiac rhythm ${ }^{(5)}$. Lung ultrasound is useful both for the monitoring of increasing exudate, as well as in decompression of pleural cavities ${ }^{(12,13)}$.

\section{Vascular criteria for pneumonia in TLUS}

In the case of detected abnormality, ultrasonography should be supplemented with colour-Doppler imaging. Inflammatory pulmonary lesions of bacterial aetiology are characterised by a typical tree-like vascular pattern within a consolidation, with vessels running from the centre to the periphery of the lesion ${ }^{(14)}$. Assessment may be also based on the blood flow spectrum and differentiation between pulmonary and bronchial arteries ${ }^{(5)}$.

\section{Limitations of TLUS in the assessment of lower respiratory inflammation}

The main limitations of TLUS include the lack of possibility to visualise the total lung surface area, which is limited by thoracic bone structures, the scapula, sternum and bony elements of the ribs in particular, as well as the lack of possibility to visualise pathological lesions that are not directly adjacent to the pleura, and which account for about $8 \%$ of respiratory pathologies ${ }^{(3,12)}$. Proper training and experience of the operator are also important. It can be assumed that TLUS should be preferably performed by a clinician familiar with patient's medical history, and thus able to interpret the image appropriately to the given clinical situation ${ }^{(15)}$.

\section{AIM OF THE PAPER}

The aim of this paper was to assess the utility of transthoracic lung ultrasound as an alternative to chest radiography in children with clinical manifestations of acute lower respiratory infection. 


\section{MATERIALS AND METHODS}

A total of 63 patients aged between 1 month and 18 years, hospitalised in the Department of Paediatrics, Paediatric Nephrology and Allergology between 2017 and 2019 were qualified for the study. The study group included 44 patients with symptoms of respiratory tract infection. The control group included 19 patients with no signs of lower respiratory infection who underwent ultrasound for other indications, such as cardiac diagnosis.

At baseline, medical history of all patients was assessed for clinical symptoms of respiratory infection based on an author's original questionnaire completed by attending physicians, which included clinical, auscultatory and percussion symptoms. Routine blood tests (blood cell count, including white blood cells and platelet count, haemoglobin levels) were performed and inflammatory markers were measured (CRP, ESR, procalcitonin).

Lung ultrasound was performed in patients before or after chest radiography (not later than 48 hours before or after $\mathrm{X}$-ray). TLUS was performed using at least two transducers: a convex 5-1 MHz transducer (8-5 MHz microconvex in younger children) and a linear $12-5 \mathrm{MHz}$ transducer. Individual segments of both lungs were assessed in a sitting or lying position, by moving the transducer along the intercostal space, both on the anterior and posterior surfaces of the chest, using longitudinal and transverse views. The presence of $\geq 3 \mathrm{~B}$-line artifacts in one intercostal space, consolidations, dynamic or static air bronchogram (air trapping), pleural fluid and foci of atelectasis were considered abnormal, as in accordance with the 2018 recommendations of the Polish Ultrasound Society ${ }^{(6)}$.

We used Philips EPIQ 5 ultrasound machines, and the examinations were performed by paediatricians (non-radiologists) trained in ultrasonography (training confirmed by

\begin{tabular}{|c|c|c|}
\hline Variable & $\begin{array}{c}\text { Study group } \\
(n=44)\end{array}$ & $\begin{array}{c}\text { Control group } \\
(n=19)\end{array}$ \\
\hline $\begin{array}{l}\text { Age [years] } \\
\text { (mean } \pm S D)\end{array}$ & $4.3 \pm 4.4$ & $6.5 \pm 3.8$ \\
\hline Sex [M:F] & $22: 22$ & $12: 7$ \\
\hline $\begin{array}{l}\text { Body weight }[\mathrm{kg}] \\
\text { (mean } \pm \text { SD) }\end{array}$ & $19 \pm 13.6$ & $25 \pm 14.0$ \\
\hline $\begin{array}{l}\text { Height }[\mathrm{cm}] \\
(\text { mean } \pm \text { SD) }\end{array}$ & $101 \pm 32.5$ & $118 \pm 27.1$ \\
\hline $\begin{array}{l}\text { CRP }[\mathrm{mg} / \mathrm{dL}] \\
\text { (median, } \mathrm{Q}_{25}-\mathrm{Q}_{75} \text { ) }\end{array}$ & $3.0 \pm 4.8$ & $0.1 \pm 0.1$ \\
\hline $\begin{array}{l}\text { WBC }\left[\times 10^{9} / L\right] \\
(\text { mean } \pm S D)\end{array}$ & $12.5 \pm 4.7$ & $7.4 \pm 1.8$ \\
\hline $\begin{array}{l}\mathrm{RBC}\left[\times 10^{12} / \mathrm{L}\right] \\
(\text { mean } \pm \text { SD) }\end{array}$ & $4.5 \pm 0.5$ & $4.7 \pm 0.3$ \\
\hline $\begin{array}{l}\text { Haemoglobin [g/dL] } \\
\text { (mean } \pm S D)\end{array}$ & $12.4 \pm 1.3$ & $13.2 \pm 1.0$ \\
\hline $\begin{array}{l}\text { PLT }\left[\times 10^{9} / L\right] \\
(\text { mean } \pm S D)\end{array}$ & $354 \pm 106$ & $339 \pm 100$ \\
\hline
\end{tabular}

SD - standard deviation; CRP - C-reactive protein; WBC - white blood cells; RBC - red blood cells; PLT - platelets.

Tab. 1. Characteristics of the study and the control group

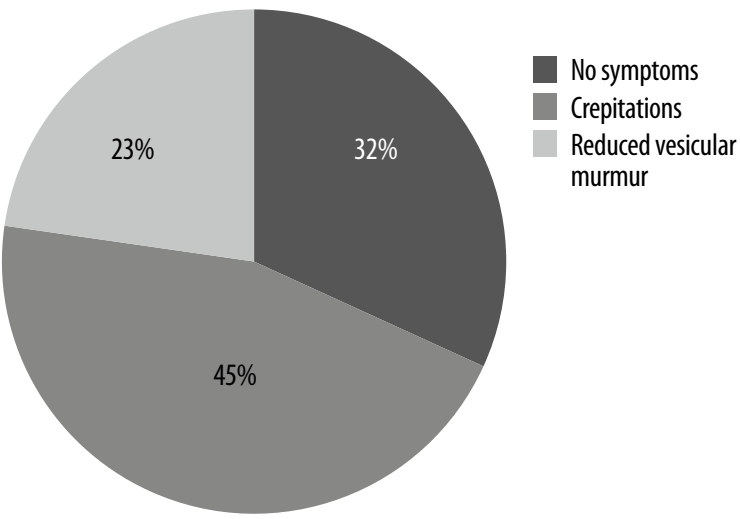

Fig. 1. Auscultatory symptoms typical of pneumonia (crepitations, reduced vesicular murmur) at admission

a paediatric ultrasonography certificate issued by the Polish Ultrasound Society).

The obtained results were compared with clinical symptoms of pneumonia and chest radiographic findings, and then were analysed statistically.

The study was approved by the Bioethics Committee of the Military Medical Chamber (No. 142/16).

The study was conducted as part of a Military Institute of Medicine statutory project (No. 452).

\section{RESULTS}

\section{Characteristics of groups}

A total of 63 patients participated in the study. The study group included 44 children (mean age $4.3 \pm 4.4$ years), and the control group included 19 children (mean age $6.5 \pm 3.8$ years).

The characteristics of the study and the control group is shown in Tab. 1.

\section{Symptoms}

We thoroughly assessed symptoms due to which the children were reported to the Department. Fever and cough were observed in 28/44 (64\%) and 42/44 (95\%) patients, respectively. Dyspnoea was reported for 31/44 children, accounting for $70 \%$ of the study group. Auscultatory and percussion symptoms, i.e. crepitations, rales, reduced vesicular murmur, and dull percussion note, which are typical of pneumonia, were present in 30/44 (68\%) patients (Fig. 1). Uncertain clinical manifestations of pneumonia were observed in $14 / 44$ patients (32\%) - physical examination revealed fever, wheezing or dry rales on auscultation, and excessively resonant sound on percussion.

\section{Aetiology}

Nasal swab for respiratory syncytial infection was performed in 11/44 children, with positive findings in 3 cases. 


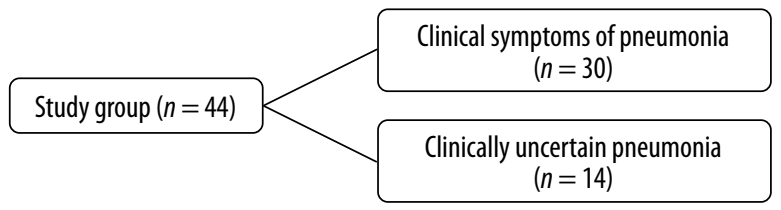

Fig. 2. Classification into groups based on the clinical symptoms of pneumonia

Infection with Mycoplasma pneumoniae was confirmed in 10/20 children with clinically suspected pneumonia of atypical aetiology.

\section{Clinical symptoms and diagnostic imaging findings}

Clinical symptoms of pneumonia were presented by $30 / 44$ (68\%) children in the study group (Fig. 2).

Radiographic lesions were detected in 26/30 (87\%) children with clinical symptoms of pneumonia. Such lesions were also present in $11 / 14$ patients with no typical symptoms of pneumonia (Fig. 3).

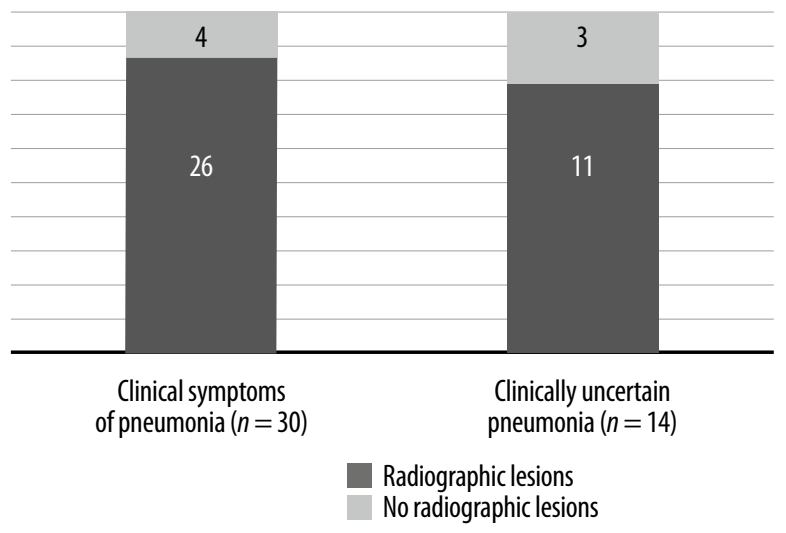

Fig. 3. Radiographic lesions in the study group of children with the symptoms of pneumonia and with clinically uncertain pneumonia

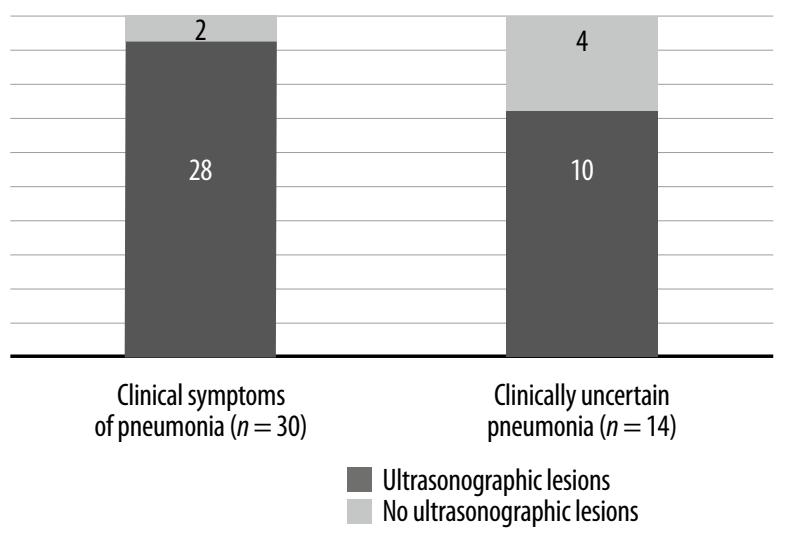

Fig. 4. Ultrasonographic lesions in the study group of children with clinical symptoms of pneumonia and with clinically uncertain pneumonia
Ultrasonographic pulmonary lesions indicative of inflammation were present in $28 / 30$ children with clinical symptoms of pneumonia. Ultrasonographic lesions were also observed in 10/14 children with clinically uncertain pneumonia (Fig. 4). Radiographic and ultrasonographic lesions typical of pneumonia were found in 25/30 children with clinical manifestations of pneumonia; diagnostic imaging showed no evidence of disease in 1/30 children (Fig. 5, Tab. 2).

Radiographic and ultrasonographic lesions typical of pneumonia were detected in $8 / 14$ children with clinically uncertain pneumonia; such lesions were not detected in $2 / 14$ patients (Fig. 6, Tab. 2).

In the control group, bilaterally reduced vesicular murmur was detected in $1 / 19$ patients. No auscultatory signs typical of pneumonia were detected in other patients.

No radiological or ultrasonographic findings suggesting pneumonia were found in any of the patients in the control group.

\section{DISCUSSION}

In recent years, there has been a growing interest in transthoracic lung ultrasound. Paediatric patients, in whom

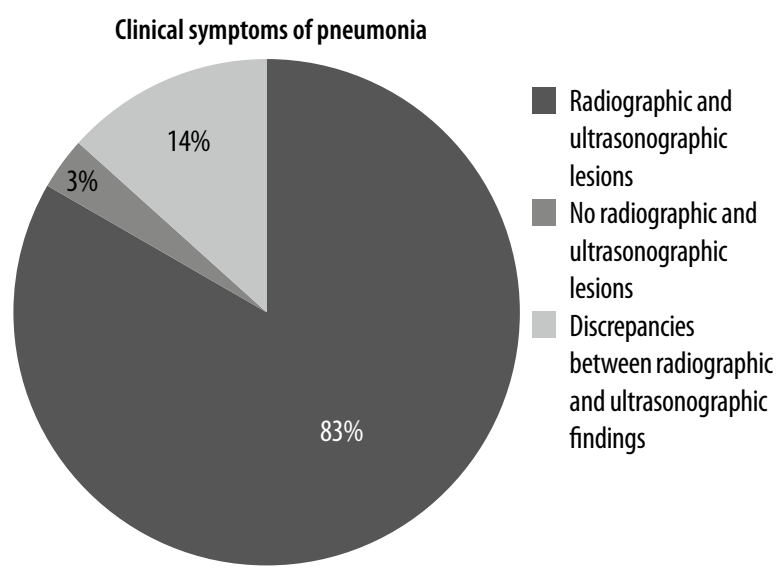

Fig. 5. Correlation between ultrasound and radiographic images in children with clinical diagnosis of pneumonia

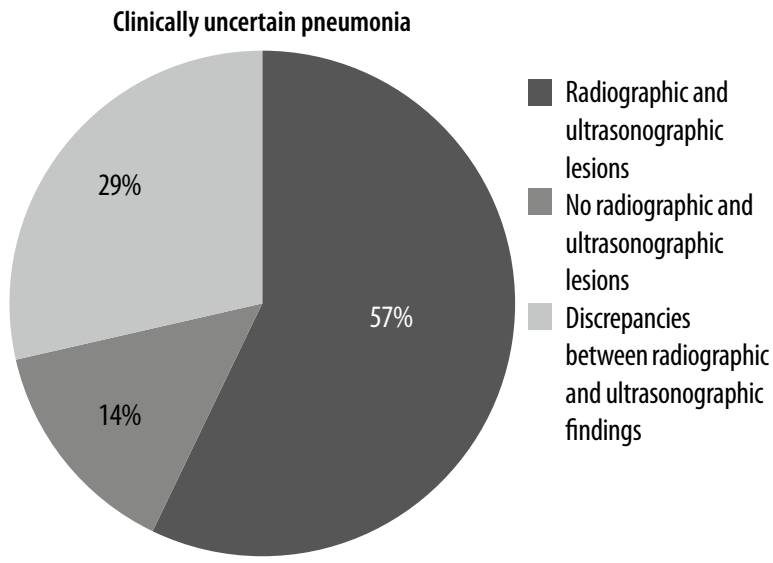

Fig. 6. Correlation between ultrasound and radiographic images in children with clinically uncertain pneumonia 


\begin{tabular}{|c|c|c|c|c|c|c|}
\hline \multirow{3}{*}{$\begin{array}{l}\text { Ultra- } \\
\text { sound }\end{array}$} & \multirow{2}{*}{\multicolumn{2}{|c|}{$\begin{array}{c}\begin{array}{c}\text { Clinical signs of } \\
\text { pneumonia }\end{array} \\
\text { X-ray } \\
\end{array}$}} & \multirow[t]{2}{*}{$n$} & \multirow{2}{*}{\multicolumn{2}{|c|}{$\begin{array}{c}\begin{array}{l}\text { Clinically uncer- } \\
\text { tain pneumonia }\end{array} \\
\text { X-ray } \\
\end{array}$}} & \multirow{3}{*}{$\begin{array}{c}n \\
\text { Total }\end{array}$} \\
\hline & & & & & & \\
\hline & $\begin{array}{c}\text { X-ray } \\
(+)\end{array}$ & $\begin{array}{c}\text { X-ray } \\
(-)\end{array}$ & Total & $\begin{array}{c}\text { X-ray } \\
(+)\end{array}$ & $\begin{array}{c}\text { X-ray } \\
(-)\end{array}$ & \\
\hline US (+) & 25 & 3 & 28 & 8 & 1 & 9 \\
\hline US (-) & 1 & 1 & 2 & 3 & 2 & 5 \\
\hline Total & 26 & 4 & 30 & 11 & 3 & 14 \\
\hline
\end{tabular}

Tab. 2. A comparison of ultrasonographic and radiographic findings in patients with clinical symptoms of pneumonia and clinically uncertain pneumonia

lung ultrasound is particularly promising due to high diagnostic efficacy, short duration and absence of proven adverse effects, represent a special group of patients. Furthermore, the examination may be freely repeated, which is important for disease monitoring and decisions on treatment modifications. The growing access to ultrasound machines in hospital facilities should encourage clinicians to participate in lung ultrasound training programmes in order to master the technique of image acquisition and interpretation.

Community-acquired pneumonia is a common infection in children, with an incidence of approximately 156 million/year, with children less than 5 years of age accounting for the majority of cases in developing countries ${ }^{(1)}$. Finnish research showed that most children $<5$ years of age and about half of those $>5$ years of age are hospitalised ${ }^{(2)}$. Depending on the patient's age, pathogenesis and the aetiological factor, infections have a heterogeneous spectrum of clinical symptoms characterised by high variability and varying severity. It is estimated that they are ultimately diagnosed in $20-50 \%$ of patients with increased body temperature, cough, tachypnoea, tachycardia, and crepitations on auscultation ${ }^{(16)}$. Typical symptoms of pneumonia may be less pronounced in paediatric patients. Chest radiography is a routine imaging technique, which is performed in the anteroposterior projection in children ${ }^{(1)}$. Although up-to-date literature data determining the sensitivity and specificity of X-ray in the diagnosis of pneumonia are missing, chest radiography is used in the clinical practice particularly in cases of severe clinical symptoms, not only to detect lesions, but also to assess their nature, location, potential complications, as well as for treatment monitoring ${ }^{(17)}$.

Our study proved the usefulness of ultrasound in the diagnosis of lower respiratory tract infections in children. Ultrasound and radiography confirmed pneumonia in $28 / 30(93 \%)$ and $26 / 30(84 \%)$ patients with typical symptoms of pneumonia, respectively (Tab. 2). Positive ultrasound corresponded with positive radiography in $25 / 26$ (96\%) patients. It should be noted, however, that $3 / 28$ (10.7\%) patients with positive ultrasound had negative radiography. Ultrasonography detected typical signs of pneumonia (consolidations, air bronchogram) in these patients. Positive ultrasonographic and radiographic findings were reported for 10/14 (71\%) and 11/14 (78\%) patients with clinically uncertain signs of pneumonia.
Inconsistent findings were obtained in $4 / 14$ patients. Negative ultrasound findings were reported for $3 / 11$ patients with positive $\mathrm{X}$-ray; radiography detected bronchopulmonary parenchymal lesions in these patients. Normal radiographic findings were reported for $1 / 19$ patients with positive ultrasound (Tab. 2).

Similar findings are presented by other authors. In their multicentre study, Reissig et al. showed that pneumonia was correctly diagnosed using ultrasound and radiography in 211/299 (92.1\%) and 199/299 (86.9\%) adult patients, respectively. On the other hand, TLUS and X-ray excluded pneumonia in 127/133 (95.5\%) and 122/133 (91.7\%) patients, respectively. Both groups included between 10 and 20 patients with different imaging findings. Sensitivity and specificity of ultrasound in the diagnosis of pneumonia were $93.4 \%$ and $97.7 \%$, respectively ${ }^{(18)}$. The usefulness of ultrasonography was also demonstrated in the paediatric population. A metaanalysis by Pereda et al. showed sensitivity and specificity of TLUS of $96 \%$ and $93 \%$, respectively ${ }^{(19)}$. Many authors emphasise that basic training in lung ultrasound is sufficient to use this technique, and the results obtained by non-radiologists are satisfactory. In a study by Esposito et al., ultrasound was performed by resident paediatric doctors who underwent training in lung ultrasound. Their findings were comparable with radiography, with sensitivity and specificity of $97.9 \%$ and $94.5 \%$, respectively ${ }^{(3)}$. Anatomical differences in children, which facilitate ultrasound imaging, such as a smaller volume of lung tissue, shorter and narrower chest, also play an important role ${ }^{(11)}$. Furthermore, unlike in adults, abnormalities detected during lung ultrasound in children are significantly less likely to require differentiation with other respiratory pathologies, such as cancer, pulmonary embolism or chronic inflammation.

We are aware that our study has some limitations. A larger patient population would allow for a more detailed statistical analysis of the obtained results, determination of ultrasound sensitivity and specificity in particular. The discrepancy of results between imaging techniques results from the fact that not all pathological lesions are detectable in both radiography and ultrasound. Radiography is superior in visualising hila and bronchopulmonary parenchymal lesions, which are undetectable in TLUS, whereas ultrasound shows higher sensitivity in detecting pleural fluid and subpleural consolidations $^{(7)}$.

Although TLUS will not replace radiography, its widespread use could limit patient exposure to ionising radiation. Lung ultrasound may be first-line diagnostic modality in paediatric patients with suspected lower respiratory infection; however, radiography still plays a decisive role in doubtful cases.

\section{CONCLUSIONS}

Transthoracic lung ultrasound is a useful tool for the assessment of lower respiratory inflammation in children. Ultrasonographic findings are comparable with those in radiology, which is considered a reference standard. 


\section{Conflict of interest}

The authors do not report any financial or personal connections with other persons or organisations, which might negatively affect the contents of this publication and/or claim authorship rights to this publication.

\section{References}

1. Krenke K, Kulus M: Choroby układu oddechowego. In: Kawalec W, Grenda R, Ziółkowska H (eds.): Pediatria. Vol. 1, Wydawnictwo Lekarskie PZWL, 2015: 288-350.

2. Hryniewicz W, Albrecht P, Radzikowski A et al.: Rekomendacje postępowania w pozaszpitalnych zakażeniach układu oddechowego. Narodowy Instytut Leków, Warszawa 2017: 141-160.

3. Esposito S, Papa SS, Borzani I et al.: Performance of lung ultrasonography in children with community-acquired pneumonia. Ital J Pediatr 2014; 40: 37

4. Lichtenstein DA, Lascols N, Mezière G et al.: Ultrasound diagnosis of alveolar consolidation in the critically ill. Intensive Care Med 2004; 30: 276-281.

5. Reissig A, Gramegna A, Aliberti S: The role of lung ultrasound in the diagnosis and follow-up of community-acquired pneumonia. Eur J Intern Med 2012; 23: 391-397.

6. Buda N, Kosiak W, Radzikowska E et al.; Polish Committee on Lung Ultrasound (PC-LUS) for POLLUS-IM: Polish recommendations for lung ultrasound in internal medicine (POLLUS-IM). J Ultrason 2018; 18: 198-206.

7. Kryger M, Kosiak W: Rola przezklatkowej ultrasonografii płuc u dzieci. Pediatr Med Rodz 2014; 10: 386-396.

8. Michalczuk M, Chudoba A, Sybilski AJ: Badanie USG przezklatkowe w ręku alergologa. Podstawy przezklatkowego badania USG. Alergol Pol 2016; 3: 69-74.
9. Lichtenstein DA: Lung ultrasound in the critically ill. In: Vincent JL (ed.): Yearbook of Intensive Care and Emergency Medicine. Springer, Heidelberg 2004: 625-644.

10. Basile V, Di Mauro A, Scalini E et al.: Lung ultrasound: a useful tool in diagnosis and management of bronchiolitis. BMC Pediatr 2015; 15: 63.

11. Riccabona M: Ultrasound of the chest in children (mediastinum excluded). Eur Radiol 2008; 18: 390-399.

12. Lai SH, Wong KS, Liao SL: Value of lung ultrasonography in the diagnosis and outcome prediction of pediatric communityacquired pneumonia with necrotizing change. PLoS One 2015; 10: $\mathrm{e} 0130082$.

13. Ho MC, Ker CR, Hsu JH et al.: Usefulness of lung ultrasound in the diagnosis of community-acquired pneumonia in children. Pediatr Neonatol 2015; 56: 40-45.

14. Iorio G, Capasso M, De Luca G et al.: Lung ultrasound in the diagnosis of pneumonia in children: proposal for a new diagnostic algorithm. PeerJ 2015; 3: e1374.

15. Trinavarat $P$, Riccabona $M$ : Potential of ultrasound in the pediatric chest. Eur J Radiol 2014; 83: 1507-1518

16. Przybyłowski T: Zapalenie płuc w różnych grupach wiekowych. Med Dypl 2011; 2: 66-77.

17. Ptak J, Pawłowski J, Bestry I: Badania obrazowe w zapaleniach płuc u dorosłych. Pneumonol Alergol Pol 2011; 79: 57-66.

18. Reissig A, Copetti R, Mathis G et al.: Lung ultrasound in the diagnosis and follow-up of community-acquired pneumonia: a prospective, multicenter, diagnostic accuracy study. Chest 2012; 142: 965-972.

19. Pereda MA, Chavez MA, Hooper-Miele CC et al.: Lung ultrasound for the diagnosis of pneumonia in children: a meta-analysis. Pediatrics 2015; 135: 714-722. 